\title{
The Incidence of Sexually Transmitted Disease at Ciracas Primary Health Care, East Jakarta
}

\section{Saudatina Arum Maujudah ${ }^{1}$ and Dewi Susanna ${ }^{2}$}

${ }^{1}$ Postgraduate Student Faculty of Public Health, Universitas Indonesia, Depok, Indonesia

${ }^{2}$ Faculty of Public Health, Universitas Indonesia, Depok, Indonesia

\section{Abstract}

Sexually Transmitted Disease (STD) is a worldwide public health problem and become significant causes of maternal, perinatal mortality and illness. This research analyzed the incidence of STD at STD Clinic, Ciracas Primary Health Care, East Jakarta, in 2010.

The association among socio-demographic (age, sex, occupation, education, civil mobilization, marital status, knowledge), environment (localization area), behavior (multi-partner sexual behavior, first sexual activity, wearing condom behavior, douching/vaginal washing, drug users, dry sex, rape/sexual assault, sexual traditional practices) and health service factors (supply of condoms, late treatment, irrational use of antibiotics, contraception, unsafe medical procedures, health promotion) with incidence of stocktickerSTD were investigated by cross-sectional study design. Eightyfive samples were chosen and interviewed by using a self-constructed questionnaire. Genital and other body fluid, as well as blood samples, were analyzed to find out the incidence of infection.

It found that the total prevalence of STD was 34.2\% (consist of gonorrhea $22.4 \%$, syphilis 7.1\% and HIV 4.7\%). By bivariate analysis, a significant relationship found between STD incident and age (OR 2.8 for age 16-34 years old); sex (OR 0.57 for women); residency (OR 0.25 for Jakarta resident); sexual behavior (OR 5.11 for multi-partner sexual conduct); and drug users (OR 5.19).

Keywords: Sexually Transmitted Disease (STD); sociodemographic; environment; behavior; health service

\section{Introduction}

Selection and Peer-review under the responsibility of the $2 \mathrm{nd}$ International Meeting of Public Health 2016 Conference Committee.

\section{S OPEN ACCESS}

Sexually Transmitted Disease (STD) is a worldwide public health problem and become significant causes of maternal, perinatal mortality and illness. The real incidence and prevalence in many countries are not known. Report of the World Health Organization (WHO) declares 250 million new cases of STD happened every year, including gonorrhea and syphilis, and the number of rate increases. A source from Directorate General of Disease Control and Environmental Health, Ministry of Health until August 30th, 2009, Jakarta was the highest prevalence of STD (i.e., chlamydia 6.0\%; gonorrhea 
1.3\% and syphilis $0.8 \%$ ). The second highest prevalence is Surabaya (i.e., chlamydia 5.7\%; gonorrhea $1.2 \%$, syphilis $1.6 \%$ ), and the third is Medan (i.e., $5.3 \%$ prevalence of chlamydia and $2.4 \%$ of syphilis). East Jakarta is a region of STD's high population at risk. The purpose of the research was to find the incidence, types and influence factor of STD in Caracas Primary Health Care. This research analyzed the incidence in STD Clinic, Ciracas Primary Health Care, East Jakarta in 2010.

STD issue is vital because STD increases the risk of HIV-AIDS which 5-9 times greater than those who were never exposed. STD causes some effects and complications, such as ectopic pregnancy, pelvic inflammatory disease, prematurity, miscarriage, fetal death, congenital infections, chronic disability, cancer, infertility, and death. The incidence of STD in Ciracas Public Health Center increased from 2008-2009 and there had been no research about the influence factors of the incidence of STD. Therefore, researchers wanted to know the incidence of STD, the types and factors that influence the incidence of STD in Ciracas Primary Health Care.

\section{Methods}

The incidence of stocktickerSTD was investigated by cross-sectional study design. Eighty-five samples were chosen and interviewed by using a self-constructed questionnaire. Genital and other body fluid, as well as blood samples, were analyzed to find out the incidence of infection. This research took April - June 2010 in STD Clinic's of Ciracas Primary Health Care, East Jakarta. Data analysis used univariate and bivariate chi-square test.

\section{Results}

This research associated between socio-demographic (age, sex, occupation, education, civil mobilization, marital status, knowledge), environment (localization area), behavior (multi-partner sexual behavior, first sexual activity, wearing condom behavior, douching/vaginal washing, drug users, dry sex, rape/sexual assault, sexual traditional practices) and health service factors (supply of condoms, late treatment, irrational use of antibiotics, contraception, unsafe medical procedures, health promotion) with incidence of STD. From 22 variables, five variables had significant correlation such as age, sex, residency, multi-partner behavior, drug users. 
TABLE 1: Respondents Frequency Distribution.

\begin{tabular}{|c|c|c|c|c|c|}
\hline Description & Amount & $\begin{array}{l}\text { Percentage } \\
\text { (\%) }\end{array}$ & Description & Amount & $\begin{array}{c}\text { Percentage } \\
\text { (\%) }\end{array}$ \\
\hline Age & & & Job & & \\
\hline $16-34$ & 55 & 64.71 & Sexual Worker & 38 & 44.7 \\
\hline$<16$ and $>34$ & 30 & 65.29 & Non Sexual worker & 47 & 55.3 \\
\hline Sex & & & Education & & \\
\hline Women & 49 & 57.6 & $<$ Senior High School & 31 & 36.5 \\
\hline Men & 36 & 42.4 & >senior High School & 54 & 63.5 \\
\hline Residency & & & Marital Status & & \\
\hline Outside Jakarta & 38 & 44.7 & High Risk & 11 & 12.9 \\
\hline Jakarta & 47 & 55.3 & Low Risk & 74 & 87.1 \\
\hline Job & & & Job of pair & & \\
\hline Does not work & 12 & 14.1 & Doesn't work & 9 & 10.6 \\
\hline Student & 3 & 3.5 & Student & 1 & 1.2 \\
\hline Housewife & 28 & 32.9 & Housewife & 8 & 9.4 \\
\hline TNI/Polri & 1 & 1.2 & TNI/Polri & 2 & 2.4 \\
\hline Government employees & 2 & 2.4 & Government employees & 10 & 11.8 \\
\hline BUMN employees & 2 & 2.4 & BUMN employees & 2 & 2.4 \\
\hline Private employees & 16 & 18.8 & Private employees & 23 & 27.1 \\
\hline Private enterprise & 2 & 2.4 & Private enterprise & 4 & 4.7 \\
\hline Services & 2 & 2.4 & Maid & 4 & 4.7 \\
\hline Maid & 4 & 4.7 & & & \\
\hline Sexual worker & 13 & 15.3 & & & \\
\hline Knowledge Level & & & Neighborhood & & \\
\hline Less & 37 & 43.5 & Prostitute area & 15 & 17.6 \\
\hline Good & 48 & 56.5 & Nonprostitute area & 70 & 82.4 \\
\hline Multipartner behaviour & & & First Sex & & \\
\hline Multipartner & 40 & 47.1 & $<20$ & 51 & 60 \\
\hline Single partner & 45 & 52.9 & $>20$ & 34 & 40 \\
\hline $\begin{array}{l}\text { Wearing condom } \\
\text { behavior }\end{array}$ & & & $\begin{array}{l}\text { The reason not wearing } \\
\text { a condom }\end{array}$ & & \\
\hline No & 73 & 85.9 & Unpleasure & 39 & 45.8 \\
\hline \multirow[t]{3}{*}{ Yes } & 12 & 14.1 & embarrassed to buy & 9 & 10.6 \\
\hline & & & cost & 3 & 3.5 \\
\hline & & & others & 22 & 25.9 \\
\hline Douching & & & Drug user & & \\
\hline Yes & 29 & 59.2 & Yes & 29 & 34.1 \\
\hline No & 20 & 40.8 & No & 56 & 65.9 \\
\hline Dry sex & & & Easy get condom & & \\
\hline Yes & 9 & 10.6 & Yes & 65 & 76.5 \\
\hline
\end{tabular}




\begin{tabular}{|c|c|c|c|c|c|}
\hline Description & Amount & $\begin{array}{c}\text { Percentage } \\
\text { (\%) }\end{array}$ & Description & Amount & $\begin{array}{c}\text { Percentage } \\
\text { (\%) }\end{array}$ \\
\hline No & 76 & 89.4 & No & 20 & 23.5 \\
\hline Get examination soon & & & Use Antibiotic & & \\
\hline Yes & 34 & 40 & Yes & 26 & 30.6 \\
\hline No & 51 & 60 & No & 59 & 69.4 \\
\hline Contraception & & & $\begin{array}{l}\text { Unsafe medical } \\
\text { procedures }\end{array}$ & & \\
\hline Yes & 24 & 49 & Yes & 15 & 30.6 \\
\hline No & 25 & 51 & No & 34 & 69.4 \\
\hline STD Health Promotion & & & $\begin{array}{l}\text { Rape/sexual assault, } \\
\text { sexual traditional } \\
\text { practices }\end{array}$ & 0 & 0 \\
\hline Yes & 41 & 48.2 & & & \\
\hline No & 44 & 51.8 & & & \\
\hline
\end{tabular}

TABLE 2: Respondents Distribution by STD Laboratory Result (Gonorrhoea, Sifilis, an HIV/AIDS).

Laboratory Result for
STD (Gonorrhoea,
Sifilis, and HIV)
Gonorrhea
Sifilis
HIV
Total

\begin{tabular}{|c|}
\hline Amount \\
\hline 19 \\
6 \\
\hline 4 \\
29 \\
\hline
\end{tabular}

\begin{tabular}{|c|}
\hline Percentage \\
\hline 22.4 \\
7.1 \\
4.7 \\
34.2 \\
\hline
\end{tabular}

TABLE 3: Respondents Distribution by Age and STD.

\begin{tabular}{|c|c|c|c|c|c|c|c|c|}
\hline \multirow[t]{3}{*}{ Age (years) } & \multicolumn{4}{|c|}{ STD } & \multicolumn{2}{|c|}{ Total } & \multirow[t]{3}{*}{ p-value } & \multirow[t]{3}{*}{ OR (95\%Cl) } \\
\hline & \multicolumn{2}{|c|}{ Yes } & \multicolumn{2}{|c|}{ No } & \multirow[b]{2}{*}{ f } & \multirow[b]{2}{*}{$\%$} & & \\
\hline & f & $\%$ & f & $\%$ & & & & \\
\hline $16-34$ & 23 & 41.8 & 32 & 58.2 & 55 & 100 & \multirow{3}{*}{0.056} & \multirow{3}{*}{$\begin{array}{c}2.875 \\
(1.013-8.157)\end{array}$} \\
\hline$<16$ and $>34$ & 6 & 20.0 & 24 & 80.0 & 30 & 100 & & \\
\hline Total & 29 & 34.1 & 56 & 65.9 & 85 & 100 & & \\
\hline
\end{tabular}

TABLE 4: Respondents Distribution by Sex and STD.

\begin{tabular}{|c|c|c|c|c|c|c|c|c|}
\hline \multirow[t]{3}{*}{ Sex } & \multicolumn{4}{|c|}{ STD } & \multicolumn{2}{|c|}{ Total } & \multirow[t]{3}{*}{ p-value } & \multirow[t]{3}{*}{ OR (95\%Cl) } \\
\hline & \multicolumn{2}{|c|}{ Yes } & \multicolumn{2}{|c|}{ No } & & & & \\
\hline & $f$ & $\%$ & $f$ & $\%$ & $\mathbf{F}$ & $\%$ & & \\
\hline Women & 5 & 10.2 & 44 & 89.8 & 49 & 100 & & \\
\hline Men & 24 & 66.7 & 12 & 33.3 & 36 & 100 & 0.000 & 0.57 \\
\hline Total & 29 & 34.1 & 56 & 65.9 & 85 & 100 & & \\
\hline
\end{tabular}


TABLE 5: Respondents Distribution by Residency and STD.

\begin{tabular}{|c|c|c|c|c|c|c|c|c|}
\hline \multirow[t]{3}{*}{ Residency } & \multicolumn{4}{|c|}{ STD } & \multicolumn{2}{|c|}{ Total } & \multirow[t]{3}{*}{ p-value } & \multirow[t]{3}{*}{ OR $(95 \% \mathrm{Cl})$} \\
\hline & \multicolumn{2}{|c|}{ Yes } & \multicolumn{2}{|c|}{ No } & & & & \\
\hline & $\mathbf{F}$ & $\%$ & f & $\%$ & $f$ & $\%$ & & \\
\hline Jakarta & 7 & 18.4 & 31 & 81.6 & 38 & 100 & \multirow{3}{*}{0.012} & \multirow{3}{*}{$\begin{array}{c}0.257 \\
(0.094-0.698)\end{array}$} \\
\hline Non-Jakarta & 22 & 46.8 & 25 & 53.2 & 47 & 100 & & \\
\hline Total & 29 & 34.1 & 56 & 65.9 & 85 & 100 & & \\
\hline
\end{tabular}

TABLE 6: Respondents Distribution by Multi-partner Behaviour and STD.

\begin{tabular}{l} 
Multi-partner \\
Behavior \\
\hline Yes \\
No \\
Total
\end{tabular}

\begin{tabular}{|c|c|c|c|}
\hline \multicolumn{4}{|c|}{ STD } \\
\hline \multicolumn{2}{|c|}{ Yes } & \multicolumn{3}{c|}{ No } \\
\hline f & $\%$ & f & $\%$ \\
\hline 21 & 52.5 & 19 & 26.4 \\
\hline 8 & 17.8 & 37 & 82.2 \\
\hline 29 & 34.1 & 56 & 65.9 \\
\hline
\end{tabular}

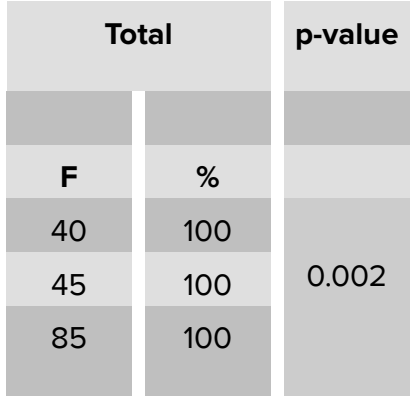

OR $(95 \% \mathrm{Cl})$

TABLE 7: Respondents Distribution by NAPZA and STD.

NAPZA
Yes
No
Total

\begin{tabular}{|c|c|c|c|}
\hline \multicolumn{4}{|c|}{ STD } \\
\hline \multicolumn{2}{|c|}{ Yes } & \multicolumn{3}{c|}{ No } \\
\hline f & $\%$ & f & $\%$ \\
\hline 17 & 58.6 & 12 & 19.1 \\
\hline 12 & 21.4 & 44 & 78.6 \\
\hline 29 & 34.1 & 56 & 65.9 \\
\hline
\end{tabular}

\begin{tabular}{|c|c|}
\hline \multicolumn{2}{|c|}{ Total } \\
\hline & \\
\hline $\mathbf{F}$ & $\%$ \\
\hline 29 & 100 \\
\hline 56 & 100 \\
\hline 85 & 100 \\
\hline
\end{tabular}

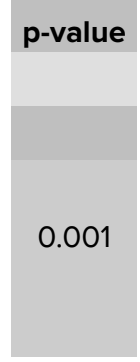

OR $(95 \% \mathrm{Cl})$

\section{Discussions}

People in the range 16-34 years old had possibility 2.8 times got STD than $<16$ and $>34$. They were high risk got STD because they were active in sexual activity, these things also related to significant result in multi-partner behavior.

People range 16-18 years old could get information from their formal institution through "Mitra Sebaya" program and informal institution through activity that involves teenage and community in reproductive ages. The Ministry of Health also spread "Aku Bangga Aku Tahu" to heal the potential effect, this promotion is to show that HIV and STD are the things must know, hope for they will think twice to do the risk activity related the cause of HIV and STD.

These data were also significant that man had possibility 1.75 times got STD than women. Actually, as literature, women are more potential to get STD than a man because women have a larger vaginal surface to be infected by germ and virus than man $(\mathrm{MOH}$, 
2005). It also related that STD diagnosis for women is more difficult to hold that man and STD on women is without symptoms. The result that women realize the importance to go to a health facility to get examination when they got sick than man (Azwar, 1999) indicated that they could get treatment early so that illness could be cured first. The consequence of this result, man must ask the partner to got examination too, so the procedure will be useful to avoid recurrent infection.

Society mobile influences the spread of STD (Daily 2007), the range of STD is influenced by travelers that got STD (Redfern, 1981). Qomariah (2001) stated that many STD case was commonly found in nomadic society but this research found that respondents living in Jakarta residency were 3.89 times to get STD than outside Jakarta residency, showing that Jakarta had high STD prevalence. It can be related that in Ciracas Public Health Service area, there is prostitute localization area, a kind of prostitute accelerating STD deployment. This prostitute localization has disbanded as formal, but the prostitute practice got spread like a small localization in some place in Ciracas Public Health Service area and outside the area. This condition can aggravate health networking; they are difficult to find. They just came to the health facility when the disease is severe, so the STD spread, and the treatment becomes longer. NGO collaboration is needed to ask sexual worker examined regularly. Health promotion about the STD risk factor is necessary to society and sex worker to decrease STD transmission.

This research showed wearing condom behavior in 13 sexual workers, most of them did not or just sometimes use a condom. Others research showed sexual workers in Gang Dolly survey where only $20 \%$ of them use condom Sedyaningsih-Mamahit (1999). This research also showed that $30.6 \%$ just sometimes used a condom. Even they use the condom, STD can happen because of inconsistency in use, and genital ulcus can spread in uncovered part. STD can spread because they do oral sex before using a condom. The reason why they did not use a condom was all about stigma and less pleasure and enjoyment. Social institution action is needed to empower people, especially sexual worker as another job to choose.

This research showed that sexual multi-partner probability was 5.1 times to get STD than a single partner, every people in sexual active potentially got STD and the risk increased for more than one partner ( $M O H$ 2008). STD can be prevented through ABC program, "A" for Abstinence; "B" for Be Faithful; " $C$ " for use Condom. Sometimes, the participant is abstinence, but their couple does sexual multi-partner so they are also at risk of suffering from STD.

Djuanda (1999) stated there was 28\% patient of syphilis and $73 \%$ patient of gonorrhea did promiscuity because of drug addiction. Drug user probability was 5.2 times to get STD, drug user potentially did free sex related with STD. 


\section{Conclusions}

It found that the total prevalence of STD was 34.2\% (consisted of gonorrhea $22.4 \%$, syphilis 7.1\%, and HIV 4.7\%). By bivariate analysis, a significant relationship found between STD incident and age (OR 2.8 for age 16-34 years old); sex (OR 0.57 for women); residency (OR 0.25 for Jakarta resident); sexual behavior (OR 5.11 for multipartner sexual conduct); and drug users (OR 5.19).

Increased knowledge of the community is needed to prevent the spread of Sexually Transmitted Diseases through health promotion. Public health needs to create a strategy on how to find the active health promotion such as smooth step approach that is necessary through the closer community and early detection that is essential to prevent the severity of STD.

This problem is a worldwide problem; it is not just a health institution problem. The big task is how to minimize public stigma. So, all people will open their mind and think rationally about the risk factor. They will be hand in hand with full awareness to prevent STD so the incidence of STD can decrease.

For the next research, it can be discussed later about STD by using the more significant sample, or specific example using in-depth interview, or compare particular sex worker in one prostitute with another prostitute so that it can be known prostitute characteristic deeper and the effective way to solve STD problem will be found.

\section{References}

[1] Ariawan, Iwan. 1998. "Besar dan Metode Pada Sampel Penelitian Kesehatan."Jurusan Biostatistik dan Kependudukan Fakultas Kesehatan Masyarakat Universitas Indonesia.

[2] Daili, Sjaiful F. dkk. "Penyakit Menular Seksual". Fakultas Kedokteran Universitas Indonesia, Jakarta (2007)

[3] Daili, Sjaiful F. Dkk. "Penyakit Menular Seksual, edisi ketiga". Fakultas Kedokteran Universitas Indonesia, Jakarta (2007)

[4] Djajadilaga. Bari Fiuddin, Abdul, dkk. "Langkah-langkah praktis paket pelayanan kesehatan reproduksi essensial di tingkat pelayanan dasar" Pusat Kesehatan Reproduksi FKUI, Jakarta (2007)

[5] File://D:/Kondom\{\%\}20Terbelenggu\{\%\}20Citra\{\%\}20Negatif\{\%\}20-

\{\%\}20HIVAIDS\{\%\}20(http-www_aids-ina_org).htm pada 6 maret 2010

[6] Hartono, B., and B. S. Kusumobroto. "Departemen Kesehatan Republik Indonesia: Profil Kesehatan Indonesia 2006." Jakarta, Indonesia: Departemen Kesehatan 
Republik Indonesia (2007).

[7] http://cintalestari.wordpress.com/2008/09/06/penyakit-menular-seksual/. Pada 6 Maret 2010

[8] http://perempuan.com/new/index.php?aid=20789\&cid=3 pada 7 April 2010

[9] http://www.aids-ina.org/modules.php?name=AvantGo\&file=print\&sid=1712 (modules) pada 2 maret 2010

[10] http://www.igama.org/index2.php?option=com_content\&do_pdf=1\&id=16 pada 8 April 2010

[11] http://www.jangkar.org/index2.php?option=com_content\&do_pdf=1\&id=479, pada 7 April 2010

[12] http://www.madinask.com/index2.php?option=com_content\&do_pdf=1\&id=4455 pada 7 mei2010

[13] http://www.pkbi-diy.info/?lang=id\&cid=7. Pada 7 Maret 2010

[14] Indonesia, Departemen Kesehatan Republik. "Laporan hasil riset kesehatan dasar (Riskesdas) Indonesia tahun 2007." Badan Penelitian dan Pengembangan Kesehatan Departemen Kesehatan RI, Jakarta (2008).

[15] Kesehatan, Indonesia Departemen Kesehatan Ditjen Bina. "Pedoman dasar infeksi menular seksual dan saluran reproduksi lainnya pada pelayanan kesehatan reproduksi terpadu-[BUKU]." (2006).

[16] Kesehatan, Indonesia Departemen. "Buku Saku Infeksi Dan Infeksi Menular Seksual Pada Pelayanan Kesehatan Terpadu". Departemen Kesehatan Republik Indonesia, Jakarta (2008)

[17] Kesehatan, Indonesia Departemen. "Pedoman dasar IMS dan ISR Pada Pelayanan Kesehatan Terpadu". Departemen Kesehatan Republik Indonesia", Jakarta (2006)

[18] Kesehatan, Indonesia Departemen. "Pedoman Komprehensif Berkala Kelompok Wanita Resiko Tinggi", Ditjen P2M dan PL, Jakarta (1999)

[19] Kesehatan, Indonesia Departemen. "Pedoman Revitalisasi Puskesmas, Edisi Satu". Departemen Kesehatan Republik Indonesia, Jakarta (2008)

[20] Kesehatan, Indonesia Departemen. "Penatalaksanaan Penderita IMS Dengan Pendekatam Sindrom, Edisi Kedua". Ditjen P2M\&PLP, Jakarta (2005)

[21] Kesehatan, Indonesia Departemen. "Penatalaksanaan Penderita Penyakit Menular Seksual Dengan Pendekatan Sindrom, Buku Pedoman Interaktif". Ditjen P2M dan PL, Jakarta (1998)

[22] Kesehatan, Indonesia Departemen. "Status Kesehatan Masyarakat Berbasis Gender" Departemen Kesehatan Republik Indonesia, Jakarta (2006) 
[23] Lestari, Herna dkk. "Implementasi Pelayanan Kesehatan Reproduksi Terpadu Mungkinkah diterapkan di Indonesia? ". Yayasan Mitra Inti, Jakarta (2007)

[24] Notoatmodjo, Soekidjo. "Promosi kesehatan dan ilmu perilaku." Aneka Cipta, Jakarta (2007).

[25] PKBI (Perkumpulan Keluarga Berencana Indonesia). "Pendidikan Seksual Untuk Remaja”, Jakarta (1998)

[26] Qomariyah, Siti Nurul, Siti Rokhmawati Darwisyah, and Lila Amaliah. Infeksi saluran reproduksi (ISR) pada perempuan Indonesia: sebuah telaah literatur. Pusat Komunikasi Kesehatan Berperspektif Jender bekerjasama dengan Ford Foundation, 2001.

[27] Sabri, Luknis, and Sutanto Priyo Hastono. "Statistik kesehatan." Edisi revisi. PT. Raja Grafindo Persada, Jakarta (2006).

[28] Statistik, Badan Pusat. "Survei Demografi Kesehatan Indonesia." Jakarta: BPS (2007).

[29] Utami, M. "Karakteristik Pasien Infeksi Menular Seksual di Klinik IMS Puskesmas kecamatan Ciracas Tahun 2008" (Skripsi). Program Sarjana Kesehatan Masyarakat, Universitas Indonesia, Depok (2009) 